\title{
LOCALISATION OF S100 PROTEIN AND ACETYLATED TUBULIN IN SHEEP PANCREAS
}

\author{
Marettová, E., Maretta, $M$. \\ Department of Morphological Disciplines, \\ University of Veterinary Medicine and Pharmacy in Košice, Komenského 73, 04181 Košice \\ Slovakia
}

elena.marettova@uvlf.sk

\section{ABSTRACT}

The pancreas plays a critical role in the control of nutritional homeostasis. It consists of two major parts, the exocrine pancreas, and the endocrine pancreas. In the present study $\mathrm{S} 100$ protein and acetylated $\alpha$-tubulin were used to identify positive structures in both the exocrine and endocrine part of the ovine pancreas. In the exocrine part of the pancreas, a positive reaction to $\$ 100$ protein was confined to centroacinar cells, intercalated, and intralobular ducts cells. In addition, the $S 100$ protein was localized in the Schwann cells of nerve fibres. On the pancreatic islets, the $\mathrm{S} 100$ protein has been observed in Schwann cells of nerve axons, where they form a fine envelope that invests the islet surface. Inside the pancreatic islets, the Schwann cells positive for S100 protein envelope the endocrine cells of the islets. The difference in positivity of the $\mathrm{S} 100$ protein was found in relation to the endocrine cells. The relationship between endocrine cell positivity and positive exocrine duct cells was discussed. Acetylated $\alpha$-tubulin (AT) was restricted to axons of the nerve fibres and was located within the connective tissue accompanying intralobular and interlobular ducts, and between secretory acini in close contact with secretory cells.

Key words: acetylated tubulin; immunohistochemistry; pancreas; $S 100$ protein; sheep

\section{INTRODUCTION}

The pancreas consists of two main parts, the exocrine pancreas, which releases digestive enzymes; and the endocrine pancreas, which releases hormones such as insulin, glucagon, pancreatic polypeptide, and somatostatin, and maintains glucose homeostasis. Both parts of the pancreas are innervated by the sympathetic and parasympathetic nervous systems, and separate pathways regulate the exocrine and exocrine pancreas. Inside the pancreas, both types of autonomic fibres transmit nerve impulses to the acinar cells and to the pancreatic islets. The autonomic nervous system affects glucose metabolism in part through a connection to the pancreatic islet. Endocrine cells in the 
Langerhans islets are well innervated by sympathetic, parasympathetic and sensory nerve fibres.

Adrenergic innervation in relation to the strong inhibitory effects of noradrenergic stimulation on insulin secretion has been studied by various authors $[2,16,28]$. It has been found that sympathetic islet innervation is increased in experimental diabetic mice [12] and that insulin secretion depends on the tone of the autonomic nervous system [28].

S100 proteins are involved in various intracellular and extracellular functions. They are involved: in the regulation of protein phosphorylation, transcription factors, $\mathrm{Ca}^{2+}$ homeostasis, dynamics of cytoskeleton components, enzyme activities, cell growth and differentiation, and the inflammatory response [14]. In addition, several authors have suggested the transduction of calcium signals by calcium-binding proteins, such as the $S 100$ protein $[3,7]$. Overexpression of the S100 protein has led to changes in the expression levels of several cytoskeletal proteins, including cytokeratins 8,18, and 19 [33]. S100 proteins play an important role in tumour development and progression due to their multifunctional properties involved in various cellular and extracellular processes [11,34].

S100 protein staining has been widely used in histological studies and diagnostic pathology to identify neuroectodermal derivatives, but has subsequently been shown to be present in normal non-nervous human tissues of various organs [17]. The S100 protein was localized in various exocrine and endocrine organs, where immunoreactivity to the S100 protein was limited to some secretory cells and to ductal cells. In human and animal pancreases, the S100 protein has been used to identify nerve structures and to identify cell types in the pancreatic islets $[1,25,32]$. S u n a $\mathrm{m}$ i et al. [30] demonstrated the three-dimensional architecture of peri-island nerve plexuses in the mouse pancreas by staining for the $\mathrm{S} 100$ protein.

Acetylated $\alpha$-tubulin as a modified form of tubulin has been found to be present in a variety of cellular structures, but has also been found to be preferentially expressed in nerve fibres, both in vivo and in vitro [8]. It is known that microtubules in axons are generally richer in acetylated tubulin than dendritic microtubules; that acetylated tubulin is unevenly distributed throughout the length of the microtubules, and that microtubules differ in acetylated tubulin levels in different regions of the axons [6]. Currently, much attention is paid to pancreatic innervation during development in connection with beta-cell regeneration and neuronal competition $[9,13,18]$ and the remodelling of pancreatic islet innervation in connection with diabetes.

The aim of this work was to study the protein S100 and acetylated $\alpha$-tubulin related to exocrine and endocrine glandular tissues and nerve structures in the sheep pancreas.

\section{MATERIALS AND METHODS}

Our investigations were carried out on six adult clinically healthy sheep of both sexes weighting between 35 and $43 \mathrm{~kg}$, age 2-4 years. The sheep were rendered insensible (anaesthetised) prior to slaughter at the University of Veterinary Medicine and Pharmacy in Košice, where they were used for education and scientific purposes. The samples of pancreas were dissected out of slaughtered sheep and the tissue samples were fixed in $10 \%$ buffered formalin and embedded in paraffin. Then $5 \mu \mathrm{m}$ thick paraffin sections were deparaffinised with xylene and dehydrated in a decreasing ethanol gradient. The sections were pre-treated with $3 \% \mathrm{H}_{2} \mathrm{O}_{2}$ in methanol to block endogenous peroxidase activity and pre-incubated with $2 \%$ goat serum to mask the unspecific binding sites. The sections were incubated with the primary antibodies S100 protein (Sigma) and acetylated $\alpha$-tubulin (Sigma), and washed in phosphate-balanced salt solution (PBS). Afterwards, the sections were incubated with biotinylated secondary antibody for $45 \mathrm{~min}$, washed in PBS, and finely incubated with avidin-biotin-peroxidase complex (ABC kits, Vector Laboratories, USA). After washing in PBS, formation of the reaction product was achieved by incubation for 10 minutes at room temperature using a mixture of an equal volume of $0.02 \%$ hydrogen peroxide and $0.1 \% 3,3^{\prime}$-diaminobenzidine tetrahydrochloride, made in Tris buffer. For negative controls, the first antibody was substituted by PBS or by normal rabbit serum. Sections were counterstained with Mayer's hematoxylin and methylene blue.

\section{Ethical considerations}

The research was approved by the UVLF Ethics Committee in accordance with applicable national and international animal welfare legislation.

The authors declare that there was no conflict of interest. 


\section{RESULTS}

The pancreas is innervated by sympathetic and parasympathetic nerve fibres. Sympathetic fibres cause vasoconstriction and inhibition of exocrine secretion and stimulate glucagon release but inhibit insulin release. Parasympathetic fibres induce secretion from acinar cells, which ultimately leads to the release of pancreatic juice, insulin and glucagon.

The pancreas is an encapsulated, tubuloacinary gland containing both exocrine and endocrine gland tissue. The exocrine pancreas forms lobules and consists of only two main cell types, namely acinar cells, which synthesize, store and secrete digestive enzymes, and ductal cells, which secrete chloride and bicarbonate. Cells in the endocrine pancreas are organized in pancreatic cell clusters, the islets of Langerhans. In the islets, insulin-secreting beta-cells are the predominant cell type. The remaining cells consist of alpha-cells that secrete glucagon, delta-cells that secrete somatostatin, and cells that secrete pancreatic polypeptide. The pancreatic stroma consists of a thin capsule that results in the formation of fine septa of connective tissue that separate the parenchyma into distinct lobules. Larger blood vessels, nerve fibres and excretory ducts take place in the septum of the connective tissue. Nerve protrusions enter the lobules and enter both exocrine and endocrine secretory cells.

In the exocrine part of the pancreas, a positive reaction to acetylated $\alpha$-tubulin has been associated with nerve fibres found mainly in the septum of the connective tissue near the blood vessels and in the larger glandular ducts. Several nerve fibres run inside the glandular tissue along with the accompanying capillaries and fine cells and connective tissue fibres (Fig. 1). The unmyelinated nerve fibres of the pancreas gave fine branches that formed plexuses around the arteries and arterioles (Fig. 1). Nerve endings positive for acetylated tubulin and S100 protein were also observed between secretory acini near the basilar part of secretory cells (Fig. 1). A positive reaction to S100 protein was observed in centroacinar cells, intercalation (Fig. 2), and intralobular ducts while interlobular ducts showed weak immunoreactions. In relation to intralobular and interlobular ducts, some S100 protein-positive nerve fibres ended in close contact with the basement membrane of the duct cells.

In addition to the above exocrine gland cells, a positive response to $\mathrm{S} 100$ protein was associated with the surface of pancreatic islet endocrine cells. At the edge of the

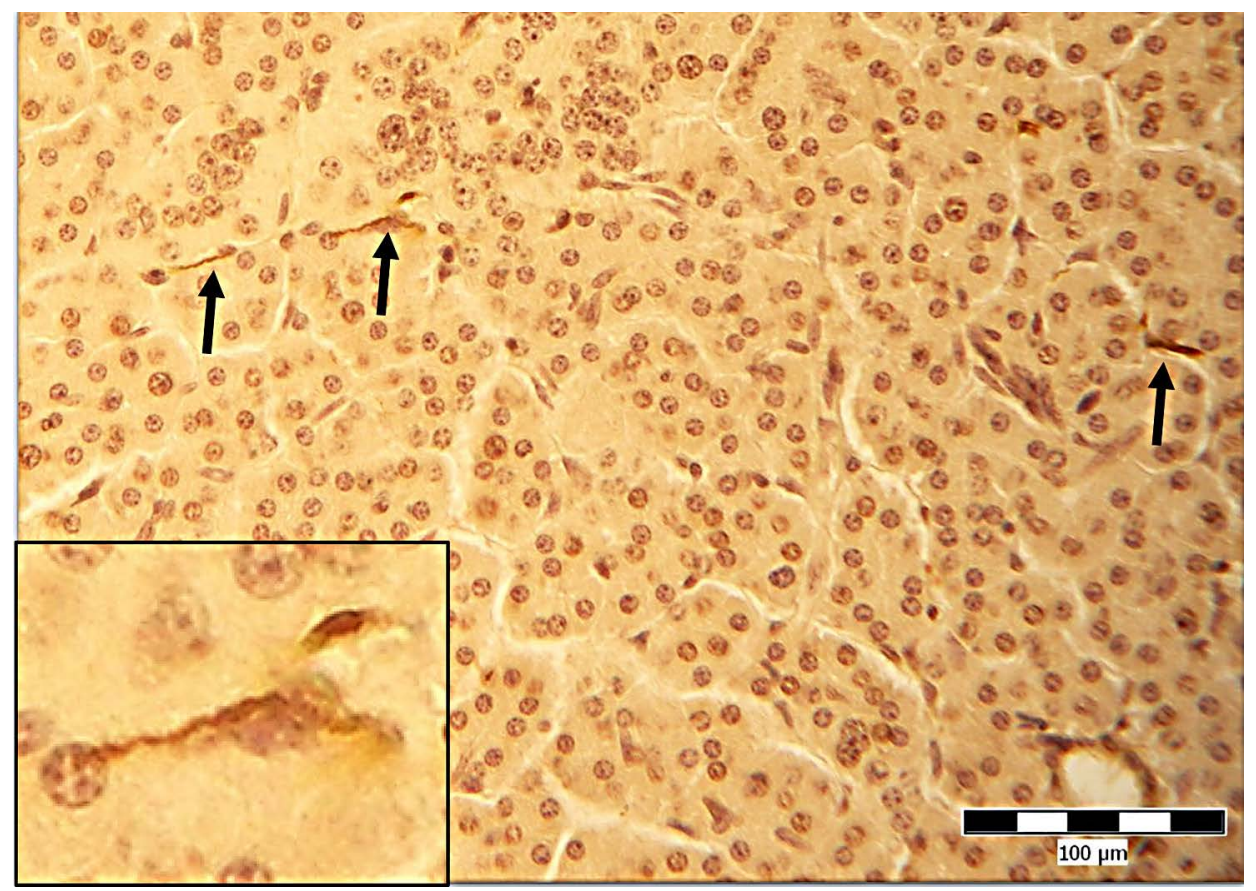

Fig. 1. Section of the pancreas stained with acetylated tubulin. Positive nerve fibres are located between the acini (arrow). Inside: Some nerve fibres get into the secretory cells 


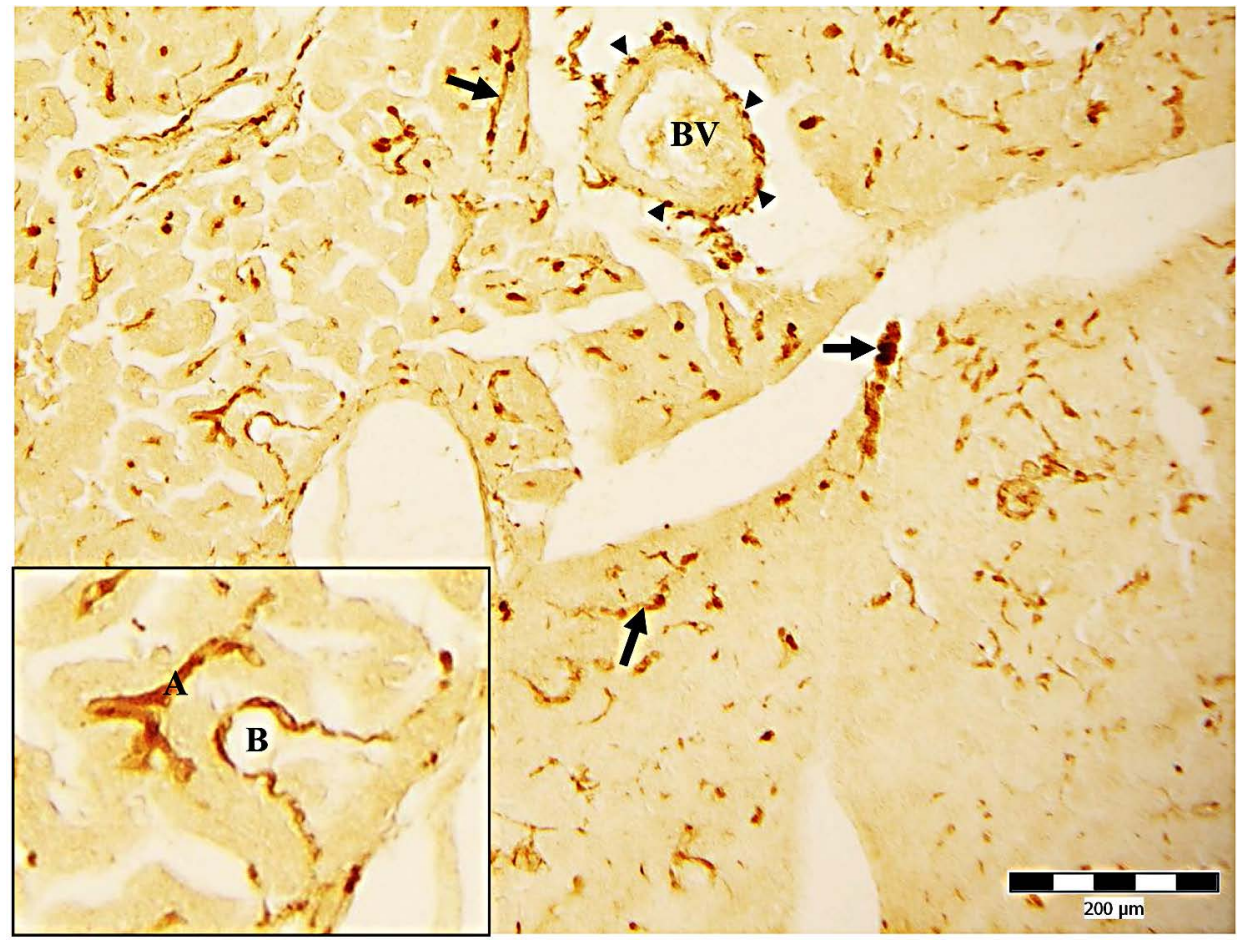

Fig. 2. Section of the pancreas stained for $S 100$ protein. Positive nerve fibres (arrowhead) located at the periphery of blood vessels (BV). Centroacinar cells (A), intercalated (B) duct give a positive reaction. The coarser nerve fibres run from the interlobular space. Thinner nerve fibres pass through the lobe (arrow)

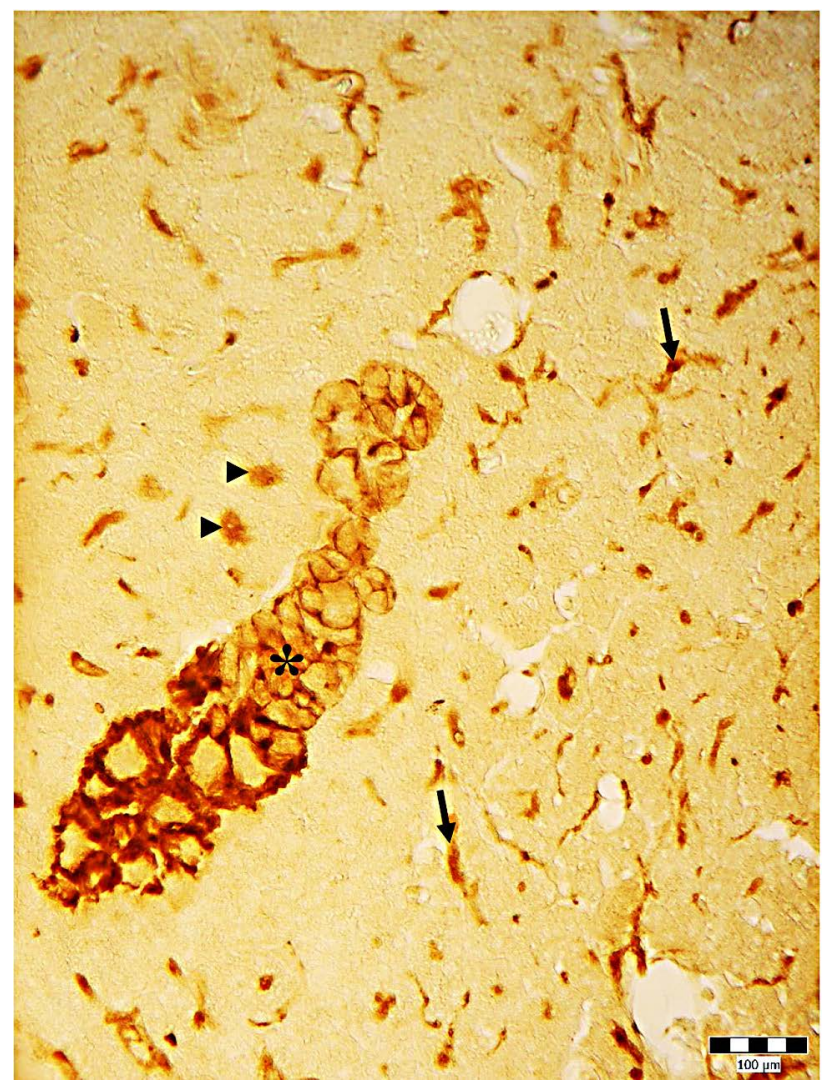

Fig. 3. Pancreas section stained for $\mathbf{S 1 0 0}$ protein. Numerous positive nerve fibres (arrow) and centroacinar cells (arrowhead) are visible. A positive reaction to $\$ 100$ protein was also observed in Schwann cells of the surrounding secretory cells of pancreatic islet (asterisk). The difference in the intensity of the colouration of the pancreatic islets is present 


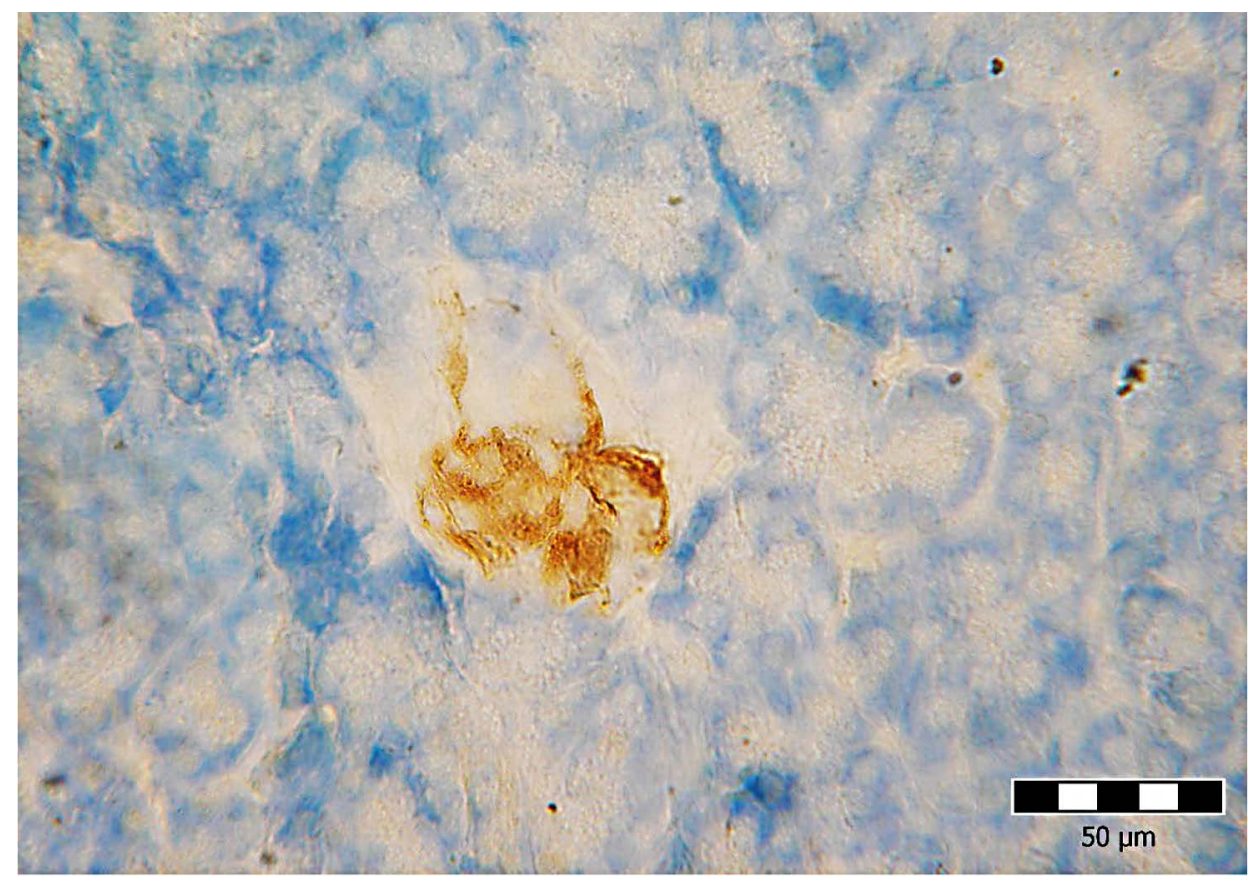

Fig. 4. Pancreas section stained for S100 protein. Some scattered islet secretory cells show a mild positive reaction

pancreatic islets and around the secretory cells, Schwann cells positive for the $S 100$ protein formed a fine envelope that invested the surface of the islet. The pancreatic islet endocrine cells were coated by cytoplasmic processes of Schwann cells positive for S100 protein (Fig. 3 and 4). Differences in the intensity of the response were observed in some parts of the islets. Pancreatic islet endocrine cells were generally negative for $\mathrm{S} 100$ protein, although a slight staining reaction was observed in some endocrine cells.

\section{DISCUSSION}

The intrapancreatic nerves in sheep formed four plexuses: perivascular, periductal, periacinar, and peri-islets. In sheep pancreas, a positive reaction to protein $\mathrm{S} 100$ was found with different intensity in the exocrine and endocrine part of the pancreas. A positive response to S100 protein and acetylated tubulin was observed in nerve fibres, which usually ran with arteries in the interlobular septa of connective tissue. Similar nerve localization has been described in humans and some animal species $[1,10]$. As in the mouse pancreas [33], the unmyelinated nerve fibres of the pancreas gave fine branches that formed plexuses around the arteries and arterioles. Although the nerve fi- bres of the networks were locally in close connection with the walls of blood vessels or the bases of secretory cells, no specialized axonal contacts were found with these tissues. In the pancreas of chinchilla [26], these structures were located in the parenchyma in close proximity to blood vessels and were also located in the walls of the pancreatic ducts and interstitial connective tissue. Adrenergic nerve fibres form a network in the adventitia of blood vessels, and individual fibres passed through the entire pancreatic parenchyma. Different extent in nerve endings has been associated with acini, islets, ducts, blood vessels, interlobular connective tissue, as well as intrapancreatic ganglion neurons in the ovine pancreas [4]. As we found in sheep, S100 protein and AT-positive nerve fibres were also observed between secretory acini in close contact with secretory cells.

The immunoreactive nerve endings of the vesicular acetylcholine transporter were distributed among the acini, while only individual cholinergic nerve fibres innervated the interlobular connective tissue. Colocalisation of vesicular acetylcholine transporter (VACh)T, tyrosine hydroxylase (TH), substance P (SP), and neuropeptide Y (NPY) has been found in different populations of nerve fibres located between acini [4]. The co-localization of vasoactive intestinal peptide (VIP) and NPY has been found 
in nerve endings located around blood vessels and acini, and in connective tissue septa. Immunoreactivities against NPY, VIP, and SP have been observed to varying degrees in nerve endings associated with acini, islets, canals, blood vessels, interlobular connective tissue, as well as in intrapancreatic ganglion neurons [5].

It has been seen that the rich nerve fibres coated with Schwann cells positive for the $\mathrm{S} 100$ protein accompany the arteries towards the islets of Langerhans. A fine network of fibres has been observed around the islets of Langerhans [26]. Both myelinated and unmyelinated fibres are observed around the perimeter of the islets. In the sheep pancreas, S100 protein-positive Schwann cells were often found at the edge of the islets, defining the islet and exocrine parenchyma [23]. Networks of unmyelinated nerve fibres consist of axons with varicose veins and Schwann cells. Schwann's islet cells combined their thin and slender processes to form a fine network or dense plexus on the islet surface in the pancreas of mice [30]. The rich innervation of islets suggests that neural regulation of secretory function is mediated by the control of blood flow in the pancreas [33]. In adult mice, it has been seen that more sympathetic fibres located on the periphery of their islets enter the islets and reach the nucleus, where mainly beta cells are located [9].

When they reached the capillaries, the nerve fibres left the arterioles and formed very loose networks in the intercellular spaces [29]. Inside the islets, the endocrine cells were enveloped by Schwann cell cytoplasmic processes. The presence of nerve fibres with a synaptic structure has occasionally been noted on the surface of the endocrine cell. In this part, Schwann cells expanded their thin membrane processes, which directly covered the basal part of several endocrine cells as a whole. Numerous axons with varicose veins were usually found on the surface of this Schwann cell membrane, but they sometimes crawled under them [30]. Some of these nerves directly synchronized with endocrine cells and affect their activity [31]. Nerve fibres entering the pancreas form a network around the perimeter of the islets referred to as peri-island plexuses [22]. Some fibres were observed upon entering the islets and ending on the surface of islet cells and innervated smooth muscle cells of blood vessels located within the islet [27]. R o d r i g u e z - D i a z, C a i c e d o [29] classified these nerve fibres as sympathetic as invasive sympathetic axons, which preferentially innervated the blood vessel smooth muscle cells. This innervation pattern suggests that sympathetic nerves may direct hormone secretion by modulating blood flow in the islets instead of acting directly on endocrine cells.

Two types of S100 positive cells can be found in the human islets of Langerhans cells located on the periphery of the islets and cells located inside the islet. Cells located at the periphery have long processes running mainly along the periphery, while cells located inside the islets generally have no processes [25]. Interactions between thin nerve fibres and endocrine cells located separately or within islets predominated [25].

In exocrine glandular tissue, a $\mathrm{S} 100$ protein positive response was observed in centroacinar cells and in all secretory ducts. The strongest response was found in centroacinar cells and in small intercalated ducts, moderate in intralobular ducts and weakest in interlobular ducts. $\mathrm{N}$ a g a s a o et al. [24] described the relationship between intercalated ducts and islets in mammals. Their results revealed intercalated ducts that responded positively to $S 100$ protein in and near the islets, with approximately $12 \%$ of the islets having intercalated channels in the vicinity and approximately $1.5 \%$ containing intercalated ducts [24]. This relationship was not found in the sheep pancreas.

It is now well known that the pancreatic endocrine cells differ from epithelial progenitors. In the human foetal pancreas, epithelial ductal cells express numerous transcription factors that regulate endocrine cell differentiation [19]. Differentiation endocrine cells temporarily retain epithelial markers and are often associated with the ductal epithelium. Common staining properties probably lie in their embryonic origin. It is well known that the structures of the nervous system originate from the neuroectoderm. Like other neuroendocrine cells, the islet cells might have originated from the neural crest. In the foetal life, their stem cells are located in the epithelium of the pancreatic ductuli [15]. K i r o v o v a et al. [21] demonstrated close integration between nervous system structures and endocrine cells in the human pancreas. As previously emphasized during the prenatal development of the pancreas, the nervous system regulates the proliferation and maturation of endocrine cells and contributes to the formation of islet architecture. It seems that contacts with the structures of the nervous system may be for the migration of epithelial progenitors into creative islets [21] and that the nervous system directly regulates the weight of endocrine cells and their maturation. 
It can be assumed that the two types of $S 100$ positive cells are important both in the morphology of the islets and in the regulation of hormones expressed by endocrine cells. The two cell types in the islets of Langerhans are distinguished in the early foetal period of the human pancreas, with two types of S100 positive cells appearing that differ in structure. Peripheral cells are morphologically similar to glial cells [25]. The cells inside the islets do not differ in structure from other endocrine cells. There were no such differences in sheep pancreas, but different intensity of antibody staining was observed between positive cells. P r o s h ch in a et al. [25] found in humans small S100-reactive cells with thin processes on the periphery of some islets. The processes of these cells often cover or surround the nerve fibres passing to the islets [20,25]. S100-positive cells with thin processes detected by the authors in human pancreas correspond to glial (Schwann) cells observed on the periphery of islets in other mammals $[30,33]$.

\section{CONCLUSIONS}

A strong response to acetylated tubulin and S100 protein has been observed in sheep pancreas in cells and nerve fibres in both exocrine and endocrine tissues of the glands. Positive nerves for both groups were complicated and were located in the connective tissue near the blood vessels accompanying the intercalate, intralobular and interlobular ducts. The nerve fibre branches enter the secretory lobes and are in close contact with secretory acini and cells. On the periphery of Langerhans islets 100-positive Schwann cells form a fine coat. The individual nerve fibres, along the blood capillaries, enter the islets and touch the endocrine secretory cells.

\section{REFERENCES}

1. Adeghate, E., 1997: Immunohistochemical identification of pancreatic hormones, neuropeptides and cytoskeletal proteins in pancreas of the camel (Camelus dromedarius). J. Morphol., 231, 185-193. DOI: 10.1002/ (SICI) 1097-4687 (199 702).

2. Ahrén, B., 2000: Autonomic regulation of islet hormone secretion-implications for health and disease. Diabetologia Rev., 43, 393-410. DOI: 10.1007/s001250051322.
3. Ahrén, B., 2006: Glucagon secretion in relation to insulin sensitivity in healthy subjects. Diabetologia Rev., 49, 117-122. DOI: 10.1007/s00125-005-0056-8.

4. Arciszewski, M. B., Zacharko-Siembida, A., 2007a: Cholinergic innervation of the pancreas in the sheep. Acta Biol. Hun., 58, 2, 151-161. DOI: 10.1556/ABiol.58.2007.2.2.

5. Arciszewski, M. B., Zacharko-Siembida, A., 2007b: A co-localization study on the ovine pancreas innervations. Ann. Anat., 189, 2, 157-167. DOI: 10.1016/j.aanat.2006.09.002.

6. Baas, P. W., Slaughter, T., Brown, A., Black, M. M., 1991: Microtubule dynamics in axons and dendrites. J. Neurosci. Res., 30, 134-153. DOI: 10.1002/jnr.490300115.

7. Ballas, K. D., Rafailidis, S. F., Demertzidis, Ch., Alatsakis, M. B., Pantzaki, A., Sakadamis, A. K., 2005: Mixed exocrine-endocrine tumour of the pancreas. J. Pancreas, 6, $449-454$.

8. Black, M. M., Baas, P. W., Humpries, S., 1989: Dynamic of $\alpha$-tubulin deacetylation in intact neurons. J. Neurosci., 9, 358-368. DOI: 10.1523/JNEUROSCI.09-01-00358.

9. Burris, R. E., Hebrok, M., 2007: Pancreatic innervation in mouse development and beta-cell regeneration. Neuroscience, 150, 592-602. DOI: 10.1016/j.neuroscience.2007.09.079.

10. Castorina, S., Romeo, R., Marccelo, M. F., 1996: Immunohistochemical study of intrinsic innervation in the human pancreas. Boll. Soc. Ital. Biol. Sper., 72, 1-7.

11. Chen, H., Chengshan, Xu., Qing'e, J., Zhihua, L., 2014: S100 protein family in human cancer. Am. J. Cancer Res., 4, 89-115.

12. Chiu, Y. C., Hua, T. E., Fu, Y. Y., Pasricha, P. J., Tang, S. C., 2012: Imaging and illustration of the perfusive mouse islet sympathetic innervation and its remodelling in injury. Diabetologia, 55, 3252-3261. DOI: 10.1007/s00125-012-2699-6.

13. Deppmann, C. D., Mihalas, S., Sharma, N., Lonze, B. E., Niebur, E., Ginty, D. D., 2008: A model for neuronal competition during development. Science, 320, 369-373. DOI: 10. 1126/science.1152677.

14. Donato, R., 2003: Intracellular and extracellular roles of S100 proteins. Microsc. Res. Tech., 60, 6, 540-51. DOI: 10.1002/ jemt.10296.

15. Dorsche von, H. H., Falkmer, S., 2000: Ontogeny of human Langerhans islets. A review of some light- and electron-microscopical, immunohistochemical, and functional data on foetal development of the endocrine pancreas. J. Evol. Biochem. Physiol., 36, 701-718.

16. Giannulis, I., Mondini, E., Cintia, F., Frontini, A., Murano, I., Barazzoni, R., et al., 2014: Increased density of inhibito- 
ry noradrenergic parenchymal nerve fibres in hypertrophic islets of Langerhans of obese mice. Nutr. Metab. Cardiovasc. Dis., 24, 4, 384-392. DOI: 10.1016/j.numecd. 2013.09.006.

17. Haimoto, H., Hosoda, S., Kato, K., 1987: Differential distribution of immunoreactive $S 100 \alpha$ and $100 \beta$ proteins in normal non-nervous human tissues. Lab. Invest., 57, 489-498.

18. Honma, Y., Araki, T., Gianino, S., Bruce, A., Heuckeroth, R., Johnson, E., Milbrandt, J., 2002: Artemin is a vascular-derived neurotropic factor for developing sympathetic neurons. Neuron., 35, 267-282. DOI: 10.1016/S0896-6273 (02)00774-2.

19. Jeon, J., Correa-Medina, M., Ricordi, C., Edlund, H., Diez, J. A., 2009: Endocrine cell clustering during human pancreas development. J. Histochem. Cytochem., 57, 811-824. DOI: 10.1369/jhc.2009.953307.

20. Krivova, Y. S., Proshchina, A. E., Chernikov, V. P., Barabanov, V. M., Saveliev, S. V., 2015: Immunohistochemical analysis and electron microscopy of glial cells in the pancreas of the foetuses and children. Bull. Exp. Biol. Med., 159, 666669. DOI: 10.1007/s 10517- 015-3043-1.

21. Krivova, Y. S., Proshchina, A. E., Barabanov, V. M., Saveliev, S. V., 2017: Neuro-Insular Complexes in the Human Pancreas, Challenges in Pancreatic Pathology. Andrada Seicean, Intech Open. Available at https:/www.intechopen.com/ books/challenges-in-pancreatic-pathology/neuro-insularcomplexes-in-the-human-pancreas. DOI: 10.5772/65059.

22. Ladukar, O. N., Pandit, R.V., 1995: Nerve supply to buffalo pancreas: Peri insular plexus. Ind. Vet. J., 72, 10, 1061-1064.

23. Mahesh, G. K. M., Ashok, P., Girish, H. M., Sharanagouda, A. A., 2017: Comparative histomorphology of endocrine pancreas in Deccani sheep and Bidri goat. MOJ Anat. Physiol., 3, 1, 17-19. DOI: 10.15406/mojap.2017.03.00079.

24. Nagasao, J., Yoshioka, K., Amasaki, H., Mutoh, K., 2002: Expression of S100 protein in intercalated duct cells of bovine pancreas. Okajimas Folia Anat. Jpn., 78, 6, 229-233. DOI: 10.2535/ofaj1936.78.6229.

25. Proshchina, A. E., Krivova, Y. S., Barabanov, V. M., Saveliev, S. V., 2015: Distribution of S100-positive cells in the islands of Langerhans of the foetal and adults human pancreas. Sovrem. Technol. Med., 7, 3, 61-66. DOI: 10,17691/stm 2015.7.3. 08

26. Radzimirska, M., Kuchinka, J., Nowak, E., Trybus, W., Szczurkowski, A., 2020: Cholinergic and adrenergic inner- vation of the pancreas in chinchilla (Chinchilla Laniger Molina). Folia Histochem. Cytobiol., 58, 1, 54-60. DOI: 10.5603/ FHC.a2020.0005.

27. Rodriguez-Diaz, R., Abdulreda, M. H., Formoso, A. L., Gans, I., Ricordi, C., Berggren, P. O., et al., 2011: Innervation patterns of autonomic axons in the human endocrine pancreas. Cell Metab., 14, 45-54. DOI: 10.1016/j.cmet. 2011. 05.008 .

28. Rodriguez-Diaz, R., Speier, S., Molano, R. D., Formoso, A., Gans, I., Abdulreda, M. H., et al., 2012: Noninvasive in vivo model demonstrating the effects of autonomic innervation on pancreatic islet function. Proc. Natl. Acad. Sci., USA, 109, 214, 56-61. DOI: 10.1073/pnas.1211659110.

29. Rodriguez-Diaz, R., Caicedo, A., 2014: Neural control of the endocrine pancreas. Best Pract. Res. Clin. Endocrinol. Metab., 28, 5, 745-56. DOI: 10.1016/j.beem.2014.05.002.

30. Sunami, E., Kanazawa, H., Hashizume, H., Takeda, M., Hatakeyama, K., Ushiki, T., 2001: Morphological characteristics of Schwann cells in the islets of Langerhans of the murine pancreas. Arch. Histol. Cytol., 64, 191-201. DOI: 10.1679/ aohc.64.191.

31. Tsui, H., Winer, S., Chan, Y., Truong, D., Tang, L., Yantha, J., et al., 2008: Islet glia, neurons, and beta cells. Ann. NY Acad. Sci., 1150, 32-42. DOI: 10.1196/annals.1447.033.

32. Uchida, T., Endo, T., 1989: Identification of cell types containing S-100b protein-like immunoreactivity in the islets of Langerhans of the guinea pig pancreas with light and electron microscopy. Cell Tissue Res., 255, 379-384. DOI: 10.1007/BF 00224121 .

33. Ushiki, T., Watanabe, S., 1997: Distribution and ultrastructure of the autonomic nerves in the mouse pancreas. Microsc. Res. Tech., 37, 399-406. DOI: 10.1002/(SICI)1097-0029 (19 970601).

34. Whiteman, H. J., Weeks, M. E., Dowen, S. E., Barry, S., Timms, J. F., Lemoine, N. R., Crnogorac-Jurcevic, T., 2007: The role of S100P in the invasion of pancreatic cancer cells is mediated through cytoskeletal changes and regulation of cathepsin D. Cancer Res., 67, 8633-8642. DOI: 10.1158/ 0008-5472.CAN-07-0545.

Received March 2, 2021

Accepted April 7, 2021 